\title{
PERSONAL NEED FOR STRUCTURE, ANXIETY, SELF-EFFICACY AND OPTIMISM
}

\author{
Alexandra PROKOPČÁKOVÁ \\ Institute of Experimental Psychology, Slovak Academy of Sciences \\ Dúbravská cesta 9, 84104 Bratislava, Slovak Republic \\ E-mail: expspro@savba.sk
}

\begin{abstract}
The aim of the study is to contribute to the explanation of mutual relations between personal need for structure, anxiety, optimism and self-efficacy. The research sample comprised 237 university students (men $n=48$ and women $n=189$ ). The following instruments were administered: Personal Need for Structure (PNS), Spielberger's Trait Personality Inventory (STPI), Generalized Self-Efficacy Scale (GSES) and Life Orientation Test - Revised (LOT-R). Significant differences between men and women in their PNS score and its subfactors - desire for structure and response to the lack of structure - were found. Women showed stronger need for structure and its subfactors. Personal need for structure and the response to the lack of structure in women was positively correlated with anxiety. Subfactor desire for structure did not show any relations with the studied characteristics. The results showed a negative relation of personal need for structure with optimism in women and no differences were found in the need for structure and its subfactors in relation to the degree of self-efficacy.
\end{abstract}

Key words: personal need for structure, anxiety, self-efficacy, optimism, pessimism

Human senses are flooded daily with information and the limited capacity for concentration raises the question of information processing, because without it we would perceive the world as an unimaginable chaos. The need to reduce this information chaos is closely related to the need to form structural representations of the outer and inner world, and to categorize events into meaningful units, which help people adapt to new events and understand them with minimum cognitive effort. The personal need for structure helps an individual to control and predict events in the complicated world (Cohen, Stotland, \& Wolfe, 1955; Neuberg \& Newsome, 1993) and, as found by Sollár and Turzáková (2014), personal need for structure also positively relates to fear of losing control.
Sarmány-Schuller (2001) says that this personality construct is related to the more basic process of categorization, which helps one to understand and differentiate the vast amount of information flooding an individual every day. Categorization based on comparison of individual stimuli (situations) makes it possible to explore things under their surface and to understand the concealed rules based on the work with the category's elements.

According to Kelly (1963), individuals create a set of personal constructs, which they then apply to outer reality. It seems that individuals perceive the world through some kind of filter, which is formed by personal constructs used in categorizing phenomena and persons. These constructs have complicated bonds with other systems of personality and its history.

DOI: $10.21909 /$ sp.2015.02.690 
If the primary motive for categorization is to provide structure, and if there are individual differences in the manner and extent of which people categorize their social world, then one of the variables differentiating individuals is personal need for structure.

Neuberg and Newsom (1993) state that people differ significantly in the extent to which they are dispositionally motivated to make cognitive structures of their world in a simple, clear-cut way. Thompson, Naccarato, Parker, \& Moskowitz (2001) in their characteristics of personal need for structure mention personality motivation and behavioral characteristics typical for individuals with different personal need for structure. Individuals with high personal need for structure prefer structure, clarity and definiteness in many situations, and are less willing to change their attitudes and stereotypes due to new information (Neuberg \& Newsom, 1993; Schaller, Boyd, Yohannes, \& O'Brien, 1995; Sarmány-Schuller, 1997, 2001; Ruiselová, 2000; Sollár, 2005, 2008). They experience ambiguity and "grey spots" as problematic and troublesome and feel averse to ambiguity. Tolerance of ambiguity is a way of perceiving and processing information concerning uncertain stimuli and situations (Frenkel-Brunswik, 1949).

Wolfradt and Engelmann (1999), together with Stranovská, Sarmány-Schuller, Munk, \& Munková (2011), describe tolerance of ambiguity as the ability to form cognitive structures, as the ability to reduce ambiguity of a new situation, i.e., tolerance of ambiguity is to some extent related to the problem of cognitive structuring, which is a form of situation complexity or information amount reduction (Sarmány-Schuller, 2000b).

Sollár and Vanečková (2012) also found that a high level in discomfort with ambigu- ity was associated with information-seeking behavior.

Problems of tolerance of ambiguity were already indicated by, e.g., Frenkel-Brunswik (1949) and Budner (1962), who perceived ambiguity as a case where an individual is literally unable to make adequate structures or categorize information. Individual with a low tolerance of ambiguity experiences stress, reacts too early and avoids ambiguous stimuli (Furnham \& Ribchester, 1995).

Similarly, Budner (1962) defined the ability to tolerate uncertainty or ambiguity as an individual's propensity to view ambiguous situations as either threatening or desirable and as those that involve novelty, complexity, or insolubility.

DeRoma, Martin and Kessler (2003) stated that low ambiguity tolerance appears to be most strongly related to valuing elements of structure and with anxiety when the valued elements of structure are missing. According to Rattan, Good and Dweck (2012), e.g., feelings of anxiety and inadequacy can interfere with efficiency in cognitive processing.

Thus, we are searching for correlates and personality determinants that participate in the preferred way of categorizing and information processing.

Based on relevant literature, SarmánySchuller (2000b) says that individuals with high personal need for structure manifest, e.g., a strong preference for simple information organization, simple judgment processes, little willingness to change attitudes when confronting new information, strong emotional responses to events disrupting adapted schemes, activities, goals, etc.

Neuberg and Newsom (1993) found that the construct personal need for structure has a two-factor character. One factor concerns the extent to which people wish to establish 
cognitive structure in everyday life (related to positive affect as response to a predictable person and well-organized events). People with high scores in this item prefer a clear and structured life and a set place for everything and the other factor of personal need of structure represents response to the lack of structure (related to negative affect as response to a chaotic, unorganized event and unpredictable persons). It concerns how people respond to unstructured and unpredictable situations. People who dislike uncertain situations or sudden, last moment changes in their plans are considered high scoring in this item.

Results of Sollár's (2008) research also support the two-factor character of the personal need for structure and thus indicate that it is a multi-dimensional construct.

These two factors have different relationships with different personality constructs (Neuberg \& Newsom, 1993; Sollár, 2008; Sollár \& Vanečková, 2012; Sollár \& Turzáková, 2014), thus, in general, they possess different implications for how people understand, experience and interact with their environment.

Significant is also the personal aspect of this problem. An individual's personality can be understood as a system of concepts (constructs, patterns), i.e., ways how s/he currently perceives the world and him/herself. According to Kováč (1985), personality has to be studied in its interfunctional bonds, i.e., as a dynamic unit comprised of a chain of mutually connected systems and subsystems.

Similarly, Sollárová and Sollár (2010) state that optimal functioning of a person occurs when the various aspects of a person are integrated into a relatively harmonious organization.
Some of the recent researches focused on the relationship between personal need for structure and several personality characteristics. For example, regarding the relation of personal need for structure and the Big Five personality factors, SarmánySchuller (1997) found in adolescents a significant positive relation of need for structure (PNS) with conscientiousness, negative significant relationship of PNS (and its subfactor RLS - response to the lack of structure) with openness, while the relationship of PNS with extraversion and with agreeableness were not significant. Neuberg and Newsom (1993) found a significant relation of the RLS with neuroticism. Also Sarmány-Schuller (1997) presents the relationship between neuroticism and personal need for structure as relatively universal in boys and girls, where, similarly to Neuberg and Newsom (1993), the RLS appears as the most significant among the PNS subfactors in this form of dependence. Ruiselová (2000), too, found significant positive relations of PNS (and especially RLS from the subfactors) with conscientiousness and neuroticism and significant negative relations of PNS (and both subfactors) with openness and extraversion.

Sarmány-Schuller (1999b) confirmed in his research the relation of ability to form cognitive structure with low uncertainty score. As stated by Budner (1962), uncertainty is perceived as a case where an individual is not fully able to form adequate structures or categorize information. Similarly, Neuberg and Newsom (1993) found that individuals who do not favor uncertain situations score high in the lack of structure.

Furthermore, it has been shown that high PNS is related to higher degree of anxiety (Sollárová \& Sollár, 2003; Sollár, 2008) and 
that PNS subfactors - response to the lack of structure and desire for structure - differ in their relation to anxiety. This corresponds to the finding of Sarmány-Schuller (1999a) concerning higher degree of anxiety related to higher RLS subfactor - response to the lack of structure.

According to Schwarzer (1993), anxiety is also related to low self-efficacy. The term self-efficacy is defined by Bandura (1977, 1997) as confidence in one's own abilities to mobilize one's own motivation, cognitive sources and processes necessary for solving a problem or completing a task. It is related to thinking about one's own competence and expresses an individual's confidence in their own internal preparedness to achieve desirable results of one's actions. The strong feeling of completeness facilitates cognitive processes and individuals with high self-efficacy choose more difficult tasks, pursue higher goals. Carr (2004) says that persons with higher self-efficacy in cognition show higher strategic elasticity, they use the future for giving structure to their lives, and they envision positive results and use them to direct their problem solving efforts.

However, self-efficacy is not the same as positive illusions or unrealistic optimism, because it is based on experience and does not lead to irrational risk-taking, it leads to courageous action that takes the ability of the individual into account.

Optimists usually use less differentiated strategies of solving situations that are related to higher resilience to uncertainty and ambiguity. Optimism expects a positive development and a positive result of some event or action. Scheier, Carver and Bridges (2001) state, that more optimistic persons are also less anxious.
On the other hand, pessimists are more sensitive to insufficiently represented situations and in uncertain situations they have better focus and are better at assessing the influencing factors, and apply more differentiated strategies to situation solving. Glaesmer, Hoyer, Klotsche and Herzberg (2008) confirmed the differentiation of factors of optimism and pessimism. They found a relative independence of both factors and they recommended a separate calculation of the optimism and pessimism scores.

\section{Problem}

The aim of this study was to investigate the relationship between the need for structure as well as its factors (desire for structure and response to the lack of structure) and other personality characteristics (anxiety, self-efficacy and optimism/pessimism), which are known to be mutually related.

Based on the research findings using PNS (Neuberg \& Newsom, 1993; SarmánySchuller, 1999a; Sollár, 2005, 2008, etc.), the following hypotheses were formulated:

1) Personal need for structure is significantly positively related to anxiety and pessimism.

2) Personal need for structure is significantly negatively related to self-efficacy and optimism.

3) Factors of personal need for structure (DFS and RLS) are related to the studied personality variables differently.

\section{Method}

Authors of the personal need for structure construct designed for its assessment a self-report scale called Personal Need for Structure (PNS - Thompson, Naccarato, 
\& Parker, 1989, In Neuberg \& Newsom, 1993), where participants express their degree of agreement or disagreement (on a six-point scale, 1 - completely disagree to 6 - completely agree) with statements focusing on the structure of the environment. The scale measures two factors related to cognitive assessment:

- Desire for Structure (DFS)

- Response to Lack of Structure (RLS)

The scale comprises 12 items, of which 5 items form the subfactor "Desire for Structure" and 7 items form the subfactor "Response to Lack of Structure". The PNS factor is the sum of scores of both subfactors. Higher score indicates higher personal need for structure, similarly, higher DFS score means higher preferences of simple structure in life and higher RLS score means stronger negative feelings in situations perceived by the individual as unsatisfyingly structured.

Spielberger's Trait Personality Inventory (STPI - Spielberger et al., 1980) - besides anxiety, which we concentrated on, it determines other personality characteristics such as curiosity, aggressiveness and depressiveness.

Life Orientation Test-Revised (LOT-R Scheier, Carver, \& Bridges, 1994) - is a sixitem measure (plus four filler items) of individual differences in optimism (subscales: optimism, or OPT and pessimism, or PESS). The extent of agreement to these items is rated across a 5-point Likert-type scale.

Generalized Self-Efficacy Scale (GSESSchwarzer \& Jerusalem, 1995) - measures level of self-efficacy - it contains 10 items with a 4-point agreement scale. It was designed with the aim to predict coping with everyday problems and the ability to adapt to different stressors.

\section{Sample}

The research sample comprised 237 university students (men: $n=48$, mean age $=$ $20.88, S D=2.55$; women: $\mathrm{n}=189$, mean age $=21.27, S D=3.9$ ). For research purposes we created extreme groups based on the \pm $1 S D$ criterion for men and women separately according to their anxiety score (men: low score $n_{1}=10$ and high score $n_{2}=8$; women: low score $n_{1}=34$ and high score $n_{2}$ $=36$ ) and self-efficacy score (men: low score $n_{1}=7$ and high score $n_{2}=8$; women: low score $n_{1}=28$ and high score $n_{2}=32$ ). Extreme groups were also formed based on LOT-R basic score (optimism - men: low score $n_{1}=13$ and high score $n_{2}=10$; women: low score $n_{1}=41$ and high score $n_{2}$ $=42$; pessimism - men: low score $n_{1}=11$ and high score $n_{2}=10$; women: low score $n_{1}=32$ and high score $n_{2}=46$; total score men: low score $n_{1}=10$ and high score $n_{2}=$ 9; women: low score $n_{1}=33$ and high score $\left.n_{2}=41\right)$.

\section{Results}

The obtained data were processes by the SPSS software. T-tests to compare the extreme groups formed by the criterion $M \pm$ $1 S D$ in anxiety, self-efficacy and optimism/ pessimism were used.

Firstly, groups of men and women in the studied characteristics of personal need for structure, anxiety, self-efficacy and optimism/ pessimism were compared (see Table 1).

It was a surprise that, as opposed to Neuberg and Newsom (1993), Sollár (2005) and Sarmány-Schuller (2000a), whose results showed no gender differences in PNS and its individual subfactors (desire for structure 
Table 1 Comparison of men and women in personal need for structure factors, anxiety, selfefficacy and optimism

\begin{tabular}{|c|c|c|c|c|c|c|c|c|c|}
\hline & \multicolumn{3}{|c|}{ Men } & \multicolumn{3}{|c|}{ Women } & \multirow[b]{2}{*}{$t$} & \multirow[b]{2}{*}{$p$} & \multirow{2}{*}{ Sig. } \\
\hline & $N_{1}$ & $M_{1}$ & $S D_{1}$ & $N_{2}$ & $M_{2}$ & $S D_{2}$ & & & \\
\hline \multicolumn{10}{|l|}{$P N S$} \\
\hline DFS & 46 & 17.70 & 5.09 & 185 & 19.89 & 4.78 & 2.649 & .010 & $* *$ \\
\hline RLS & 46 & 22.76 & 5.82 & 183 & 25.31 & 5.28 & 2.699 & .009 & $* *$ \\
\hline PNS & 45 & 40.29 & 9.04 & 180 & 45.34 & 8.93 & 3.363 & .001 & $* * *$ \\
\hline Anxiety & 45 & 19.69 & 4.95 & 185 & 21.57 & 4.66 & 2.316 & .024 & $*$ \\
\hline GSES & 45 & 31.71 & 5.12 & 188 & 30.02 & 3.86 & 2.082 & .042 & * \\
\hline \multicolumn{10}{|l|}{$L O T-R$} \\
\hline OPT & 48 & 8.10 & 2.48 & 189 & 7.94 & 2.29 & 0.411 & .682 & \\
\hline PESS & 48 & 5.17 & 2.37 & 187 & 4.64 & 2.54 & 1.361 & .177 & \\
\hline Total OPT & 48 & 14.94 & 3.96 & 187 & 15.30 & 4.19 & 0.558 & .578 & \\
\hline
\end{tabular}

and response to the lack of structure), the presented sample showed significant differences in men and women at the level of significance $p<0.01$ in both subfactors of personal need for structure, i.e., in the factors desire for structure (DFS) and response to the lack of structure (RLS), as in the total PNS score at the level of significance $p<$ 0.001 .

In comparison to men, women manifested significantly higher total personal need for structure and higher score in both subfactors of PNS, i.e., desire for structure and response to the lack of structure.

As expected, a significant difference between men and women in the degree of anxiety was found, i.e., women scored significantly higher than men in anxiety. Moreover, men achieved significantly higher self-efficacy. Gender differences in optimism/pessimism were not significant.
Based on the data of the presented sample, the obtained results were analyzed separately for the groups of men and women.

To verify the findings of Sollárová and Sollár (2003) as well as Sollár (2005), concerning significant relations of personal need for structure and anxiety, in the second step extreme groups according to anxiety levels were created.

Comparison of men with high and low anxiety showed no significant differences in the desire for structure, response to the lack of structure or total personal need for structure (Table 2).

Similarly to men, in women no significant differences in the desire for structure were found, but in the response to the lack of structure and total personal need for structure, highly anxious women scored significantly higher in comparison to low anxious women (Table 3). 
Table 2 Comparison of men with low and high anxiety in factors and total score of personal need for structure

\begin{tabular}{|c|c|c|c|c|c|c|c|c|c|}
\hline \multirow{2}{*}{ Men } & \multicolumn{3}{|c|}{ Low anxiety } & \multicolumn{3}{|c|}{ High anxiety } & \multirow{2}{*}{$t$} & \multirow{2}{*}{$p$} & \multirow{2}{*}{ Sig. } \\
\hline & $N_{l}$ & $M_{1}$ & $S D_{1}$ & $N_{2}$ & $M_{2}$ & $S D_{2}$ & & & \\
\hline \multicolumn{10}{|l|}{$P N S$} \\
\hline DFS & 10 & 17.00 & 5.81 & 7 & 16.86 & 4.74 & 0.056 & .956 & \\
\hline RLS & 10 & 18.40 & 4.38 & 7 & 21.86 & 5.93 & 1.313 & .217 & \\
\hline PNS & 10 & 35.40 & 9.28 & 7 & 38.71 & 9.78 & 0.703 & .495 & \\
\hline GSES & 10 & 36.30 & 2.58 & 8 & 28.13 & 4.02 & 4.991 & .000 & $* * *$ \\
\hline \multicolumn{10}{|l|}{$L O T-R$} \\
\hline OPT & 10 & 9.70 & 1.42 & 8 & 5.75 & 2.60 & 3.856 & .003 & $* *$ \\
\hline PESS & 10 & 3.30 & 2.50 & 8 & 6.50 & 1.41 & 3.424 & .004 & $* *$ \\
\hline Total OPT & 10 & 18.40 & 2.87 & 8 & 11.25 & 2.96 & 5.154 & .000 & $* * *$ \\
\hline
\end{tabular}

Table 3 Comparison of women with low and high anxiety in factors and total score of personal need for structure

\begin{tabular}{|c|c|c|c|c|c|c|c|c|c|}
\hline \multirow{2}{*}{ Women } & \multicolumn{3}{|c|}{ Low anxiety } & \multicolumn{3}{|c|}{ High anxiety } & \multirow[b]{2}{*}{$t$} & \multirow[b]{2}{*}{$p$} & \multirow{2}{*}{ Sig. } \\
\hline & $\overline{N_{1}}$ & $M_{1}$ & $S D_{1}$ & $\mathrm{~N}_{2}$ & $M_{2}$ & $\mathrm{SD}_{2}$ & & & \\
\hline \multicolumn{10}{|l|}{$P N S$} \\
\hline DFS & 33 & 19.61 & 5.91 & 36 & 20.58 & 3.94 & 0.800 & .427 & \\
\hline RLS & 33 & 22.97 & 5.55 & 35 & 27.09 & 4.31 & 3.399 & .001 & $* * *$ \\
\hline PNS & 32 & 42.75 & 10.56 & 35 & 47.63 & 7.01 & 2.207 & .032 & $*$ \\
\hline GSES & 34 & 33.41 & 3.65 & 36 & 27.39 & 3.74 & 6.819 & .000 & $* * *$ \\
\hline \multicolumn{10}{|l|}{$L O T-R$} \\
\hline OPT & 34 & 9.56 & 1.48 & 36 & 6.56 & 2.62 & 5.939 & .000 & $* * *$ \\
\hline PESS & 34 & 2.88 & 2.18 & 36 & 6.58 & 2.75 & 6.251 & .000 & $* * *$ \\
\hline Total OPT & 34 & 18.68 & 2.87 & 36 & 11.97 & 4.49 & 7.489 & .000 & $* * *$ \\
\hline
\end{tabular}

Note. DFS - desire for structure; RLS - response to lack of structure; PNS - personal need for structure; GSES - self-efficacy; OPT - optimism (LOT-R); PESS - pessimism (LOT-R); Total OPT - total optimism (LOT-R) 
The results showed a significant negative relation of anxiety and self-efficacy, and anxiety and optimism in men as well as women.
Next, we focused on the differences in the studied variables in men and women with low and high self-efficacy (Tables 4 and 5).

Table 4 Comparison of men with low and high self-efficacy in factors and total score of personal need for structure, anxiety and optimism

\begin{tabular}{|c|c|c|c|c|c|c|c|c|c|}
\hline \multirow{2}{*}{ Men } & \multicolumn{3}{|c|}{ Low self-efficacy } & \multicolumn{3}{|c|}{ High self-efficacy } & \multirow[b]{2}{*}{$t$} & \multirow[b]{2}{*}{$p$} & \multirow{2}{*}{ Sig } \\
\hline & $N_{1}$ & $M_{1}$ & $S D_{1}$ & $\mathrm{~N}_{2}$ & $M_{2}$ & $S D_{2}$ & & & \\
\hline \multicolumn{10}{|l|}{$P N S$} \\
\hline DFS & 7 & 17.57 & 4.96 & 8 & 20.00 & 5.45 & 0.903 & .383 & \\
\hline RLS & 7 & 21.57 & 5.85 & 8 & 18.00 & 2.93 & 1.462 & .180 & \\
\hline PNS & 7 & 39.14 & 10.27 & 8 & 38.00 & 6.61 & 0.252 & .806 & \\
\hline Anxiety & 7 & 23.71 & 4.15 & 7 & 16.00 & 4.51 & 3.330 & .006 & $* *$ \\
\hline \multicolumn{10}{|l|}{$L O T-R$} \\
\hline OPT & 7 & 7.71 & 2.36 & 8 & 9.38 & 1.77 & 1.525 & .155 & \\
\hline PESS & 7 & 7.00 & 2.16 & 8 & 3.88 & 2.23 & 2.752 & .017 & $*$ \\
\hline Total OPT & 7 & 12.71 & 2.21 & 8 & 17.50 & 2.73 & 3.749 & .002 & $* *$ \\
\hline
\end{tabular}

Note. DFS - desire for structure; RLS - response to lack of structure; PNS - personal need for structure; Anxiety - anxiety (STPI); OPT - optimism (LOT-R); PESS - pessimism (LOT-R); Total OPT - total optimism (LOT-R)

Table 5 Comparison of women with low and high self-efficacy in factors and total score of personal need for structure, anxiety and optimism

\begin{tabular}{|c|c|c|c|c|c|c|c|c|c|}
\hline \multirow{2}{*}{ Women } & \multicolumn{3}{|c|}{ Low self-efficacy } & \multicolumn{3}{|c|}{ High self-efficacy } & \multirow[b]{2}{*}{$t$} & \multirow[b]{2}{*}{$p$} & \multirow{2}{*}{ Sig. } \\
\hline & $N_{l}$ & $M_{1}$ & $S D_{l}$ & $\mathrm{~N}_{2}$ & $M_{2}$ & $S D_{2}$ & & & \\
\hline \multicolumn{10}{|l|}{$P N S$} \\
\hline DFS & 27 & 21.19 & 3.93 & 31 & 20.65 & 5.24 & 0.447 & .656 & \\
\hline RLS & 27 & 26.26 & 3.60 & 32 & 24.16 & 5.93 & 1.673 & .100 & \\
\hline PNS & 26 & 47.46 & 6.84 & 31 & 44.94 & 9.71 & 1.148 & .256 & \\
\hline Anxiety & 28 & 25.79 & 4.59 & 32 & 17.63 & 4.21 & 7.140 & .000 & $* * *$ \\
\hline \multicolumn{10}{|l|}{$L O T-R$} \\
\hline OPT & 29 & 6.31 & 2.17 & 32 & 9.41 & 2.15 & 5.581 & .000 & $* * *$ \\
\hline PESS & 29 & 5.97 & 2.82 & 32 & 3.75 & 2.68 & 3.138 & .003 & $* *$ \\
\hline Total OPT & 29 & 12.34 & 4.21 & 32 & 17.66 & 4.28 & 4.879 & .000 & $* * *$ \\
\hline
\end{tabular}

Note. DFS - desire for structure; RLS - response to lack of structure; PNS - personal need for structure; Anxiety - anxiety (STPI); OPT - optimism (LOT-R); PESS - pessimism (LOT-R); Total OPT - total optimism (LOT-R) 
No significant differences were found in personal need for structure and its subfactors related to self-efficacy in men and women. Self-efficacy is negatively related to anxiety and pessimism and positively to optimism in both genders, whereas these relations are stronger in women.

In the extreme groups formed according to the optimism score, only highly optimistic women manifested significantly lower re- sponse to the lack of structure in comparison to less optimistic women. In men, no significant differences were found in personal need for structure and its subfactors in relation to optimism (Tables 6 and 7).

Optimistic men and women achieved significantly higher self-efficacy and significantly lower anxiety.

On the other hand, pessimistic individuals were more anxious and their self-efficacy was

Table 6 Comparison of men with low and high optimism in factors and total score of personal need for structure, anxiety and self-efficacy

\begin{tabular}{|c|c|c|c|c|c|c|c|c|c|}
\hline \multirow{2}{*}{ Men } & \multicolumn{3}{|c|}{ Low optimism } & \multicolumn{3}{|c|}{ High optimism } & \multirow{2}{*}{$t$} & \multirow[b]{2}{*}{$p$} & \multirow{2}{*}{ Sig. } \\
\hline & $N_{l}$ & $M_{1}$ & $S D_{1}$ & $\mathrm{~N}_{2}$ & $M_{2}$ & $S D_{2}$ & & & \\
\hline \multicolumn{10}{|l|}{$P N S$} \\
\hline DFS & 13 & 16.69 & 4.09 & 10 & 20.10 & 4.07 & 1.987 & .061 & \\
\hline RLS & 13 & 21.62 & 5.30 & 10 & 23.40 & 5.82 & 0.758 & .458 & \\
\hline PNS & 13 & 38.31 & 8.62 & 10 & 43.50 & 5.72 & 1.732 & .098 & \\
\hline Anxiety & 13 & 23.54 & 3.53 & 10 & 18.60 & 5.10 & 2.617 & .019 & $*$ \\
\hline GSES & 12 & 28.92 & 4.12 & 10 & 34.00 & 5.71 & 2.349 & .032 & $*$ \\
\hline
\end{tabular}

Note. DFS - desire for structure; RLS - response to lack of structure; PNS - personal need for structure; Anxiety - anxiety (STPI); GSES - self-efficacy

Table 7 Comparison of women with low and high optimism in factors and total score of personal need for structure, anxiety and self-efficacy

\begin{tabular}{|c|c|c|c|c|c|c|c|c|c|}
\hline \multirow{2}{*}{ Women } & \multicolumn{3}{|c|}{ Low optimism } & \multicolumn{3}{|c|}{ High optimism } & \multirow{2}{*}{$t$} & \multirow[b]{2}{*}{$p$} & \multirow{2}{*}{ Sig. } \\
\hline & $N_{I}$ & $M_{1}$ & $S D_{1}$ & $N_{2}$ & $M_{2}$ & $S D_{2}$ & & & \\
\hline \multicolumn{10}{|l|}{$P N S$} \\
\hline DFS & 40 & 19.95 & 4.46 & 41 & 19.24 & 5.23 & 0.654 & .515 & \\
\hline RLS & 38 & 26.45 & 4.84 & 42 & 23.60 & 4.75 & 2.687 & .010 & $* *$ \\
\hline PNS & 38 & 46.55 & 7.98 & 41 & 42.93 & 8.89 & 1.910 & .060 & \\
\hline Anxiety & 40 & 25.08 & 4.31 & 41 & 19.07 & 4.43 & 6.176 & .000 & $* * *$ \\
\hline GSES & 41 & 27.98 & 3.56 & 41 & 32.49 & 3.89 & 5.482 & .000 & $* * *$ \\
\hline
\end{tabular}

Note. DFS - desire for structure; RLS - response to lack of structure; PNS - personal need for structure; Anxiety - anxiety (STPI); GSES - self-efficacy 
lower. No significant relation between pessimism and personal need for structure and its subfactors were found (Tables 8 and 9).

Differences between men and women were manifested in the relation of total optimism measured by LOT-R and personal need for structure. While in men no significant differ- ences were found, highly optimistic women manifested significantly lower personal need for structure and a lower response to the lack of structure (Tables 10 and 11).

Highly optimistic men and women (in total optimism score) manifested lower anxiety and higher self-efficacy too.

Table 8 Comparison of men with low and high pessimism in factors and total score of personal need for structure, anxiety and self-efficacy

\begin{tabular}{|c|c|c|c|c|c|c|c|c|c|}
\hline \multirow{2}{*}{ Men } & \multicolumn{3}{|c|}{ Low pessimism } & \multicolumn{3}{|c|}{ High pessimism } & \multirow{2}{*}{$t$} & \multirow{2}{*}{$p$} & \multirow{2}{*}{ Sig. } \\
\hline & $N_{l}$ & $M_{1}$ & $S D_{1}$ & $\mathrm{~N}_{2}$ & $M_{2}$ & $S D_{2}$ & & & \\
\hline \multicolumn{10}{|l|}{$P N S$} \\
\hline DFS & 11 & 18.82 & 6.68 & 10 & 17.20 & 3.82 & 0.689 & .500 & \\
\hline RLS & 11 & 20.91 & 6.70 & 9 & 20.78 & 6.53 & 0.044 & .965 & \\
\hline PNS & 11 & 39.73 & 11.61 & 9 & 37.78 & 9.09 & 0.421 & .679 & \\
\hline Anxiety & 9 & 16.22 & 4.60 & 9 & 22.67 & 4.80 & 2.908 & .010 & $* *$ \\
\hline GSES & 10 & 35.70 & 2.58 & 9 & 28.44 & 5.96 & 3.377 & .006 & $* *$ \\
\hline
\end{tabular}

Note. DFS - desire for structure; RLS - response to lack of structure; PNS - personal need for structure; Anxiety - anxiety (STPI); GSES - self-efficacy

Table 9 Comparison of women with low and high pessimism in factors and total score of personal need for structure, anxiety and self-efficacy

\begin{tabular}{|c|c|c|c|c|c|c|c|c|c|}
\hline \multirow{2}{*}{ Women } & \multicolumn{3}{|c|}{ Low pessimism } & \multicolumn{3}{|c|}{ High pessimism } & \multirow{2}{*}{$t$} & \multirow{2}{*}{$p$} & \multirow{2}{*}{ Sig. } \\
\hline & $N_{1}$ & $M_{1}$ & $S D_{1}$ & $\mathrm{~N}_{2}$ & $M_{2}$ & $\mathrm{SD}_{2}$ & & & \\
\hline \multicolumn{10}{|l|}{$P N S$} \\
\hline DFS & 31 & 19.32 & 5.47 & 45 & 20.64 & 4.75 & 1.091 & .280 & \\
\hline RLS & 32 & 24.25 & 6.51 & 45 & 26.84 & 4.70 & 1.927 & .059 & \\
\hline PNS & 31 & 43.71 & 10.71 & 44 & 47.50 & 8.45 & 1.642 & .106 & \\
\hline Anxiety & 31 & 18.61 & 4.06 & 45 & 24.56 & 4.68 & 5.887 & .000 & $* * *$ \\
\hline GSES & 32 & 30.84 & 4.10 & 46 & 28.76 & 3.41 & 2.362 & .022 & $*$ \\
\hline
\end{tabular}

Note. DFS - desire for structure; RLS - response to lack of structure; PNS - personal need for structure; Anxiety - anxiety (STPI); GSES - self-efficacy 
Table 10 Comparison of men with low and high total optimism in factors and total score of personal need for structure, anxiety and self-efficacy

\begin{tabular}{|c|c|c|c|c|c|c|c|c|c|}
\hline \multirow{2}{*}{ Men } & \multicolumn{3}{|c|}{ Low total optimism } & \multicolumn{3}{|c|}{ High total optimism } & \multirow{2}{*}{$t$} & \multirow[b]{2}{*}{$p$} & \multirow{2}{*}{ Sig } \\
\hline & $N_{l}$ & $M_{1}$ & $S D_{1}$ & $\mathrm{~N}_{2}$ & $M_{2}$ & $S D_{2}$ & & & \\
\hline \multicolumn{10}{|l|}{$P N S$} \\
\hline DFS & 10 & 16.70 & 4.37 & 9 & 19.00 & 6.04 & 0.942 & .362 & \\
\hline RLS & 10 & 22.10 & 5.95 & 9 & 20.56 & 6.19 & 0.553 & .588 & \\
\hline PNS & 10 & 38.80 & 9.52 & 9 & 39.56 & 9.88 & 0.169 & .868 & \\
\hline Anxiety & 10 & 24.30 & 3.30 & 8 & 15.25 & 3.49 & 5.595 & .000 & $* * *$ \\
\hline GSES & 9 & 28.33 & 3.28 & 9 & 35.67 & 2.45 & 5.585 & .000 & $* * *$ \\
\hline
\end{tabular}

Note. DFS - desire for structure; RLS - response to lack of structure; PNS - personal need for structure; Anxiety - anxiety (STPI); GSES - self-efficacy

Table 11 Comparison of women with low and high total optimism in factors and total score of personal need for structure, anxiety and self-efficacy

\begin{tabular}{|c|c|c|c|c|c|c|c|c|c|}
\hline \multirow{2}{*}{ Women } & \multicolumn{3}{|c|}{ Low total optimism } & \multicolumn{3}{|c|}{ High total optimism } & \multirow[b]{2}{*}{$t$} & \multirow[b]{2}{*}{$p$} & \multirow{2}{*}{ Sig. } \\
\hline & $N_{I}$ & $M_{1}$ & $S D_{1}$ & $N_{2}$ & $M_{2}$ & $S D_{2}$ & & & \\
\hline \multicolumn{10}{|l|}{$P N S$} \\
\hline DFS & 33 & 20.58 & 4.23 & 40 & 19.15 & 5.47 & 1.254 & .214 & \\
\hline RLS & 32 & 27.47 & 4.68 & 41 & 23.27 & 5.51 & 3.516 & .001 & $* * *$ \\
\hline PNS & 32 & 48.00 & 7.78 & 40 & 42.50 & 10.16 & 2.600 & .011 & $*$ \\
\hline Anxiety & 32 & 25.56 & 4.51 & 40 & 18.10 & 3.77 & 7.496 & .000 & $* * *$ \\
\hline GSES & 33 & 28.42 & 3.46 & 40 & 32.30 & 4.07 & 4.394 & .000 & $* * *$ \\
\hline
\end{tabular}

Note. DFS - desire for structure; RLS - response to lack of structure; PNS - personal need for structure; Anxiety - anxiety (STPI); GSES - self-efficacy

\section{Discussion}

The need to cognitively structure reality was studied in relation to anxiety. As mentioned above, Neuberg and Newsom (1993) identified two conceptually different factors of personal need for structure (Sollár, 2008 on Slovak data). One is related to the extent to which people wish to structure their ev- eryday life (desire for structure) and the other is a response to the lack of structure - it shows how people respond to unstructured, unforeseeable situations.

As opposed to other authors (e.g., Neuberg \& Newsom, 1993; Sollár, 2005; Sarmány-Schuller, 2000a), who found no differences in the personal need for structure between men and women, the results of the presented research show significant differ- 
ences in this characteristic. Women, in comparison to men, manifested higher total personal need for structure and higher score in both factors of personal need for structure, i.e., desire for structure and response to the lack of structure.

This means that based on the presented research and the research of other authors, the question whether men and women differ in personal need for structure could not be clearly answered, since the differences in the presented sample, as opposed to previous researches, were significant for total PNS and also its subfactors DFS and RLS. We do not know if this is some kind of an anomaly in the presented sample, which was not as large as samples used by the above mentioned authors and the number of men was smaller compared to the number of women, or if statements that men and women do not differ in PNS are not so unequivocal. According to Sarmány-Schuller (1997), cases where gender differences in psychological researches of personality or personality constructs are practically zero are relatively rare. Further verifications of this finding are necessary.

Similarly to Sollárová and Sollár (2003), whose research results showed that anxiety did not correlate with the desire for structure, the presented research results also showed no significant differences in the factor desire for structure, which was focused on simple organization of information between women as well as men with low and high anxiety.

In this context, we can also mention findings by Halama and Gurňáková (2014). These authors also found no significant correlation between desire for structure and neuroticism.

A different situation occurred when men and women with different degrees of anxiety were compared in the factor response to the lack of structure. Women, but not men, with low anxiety had a significantly lower response to the lack of structure in comparison to women with high anxiety. Sollárová and Sollár (2003) also found a significantly positive correlation between anxiety and response to the lack of structure, i.e., the higher (or lower) the personal need for structure, the higher (or lower) the anxiety.

Similarly, Sarmány-Schuller (1999b) found that individuals differ significantly in anxiety in relation to personal need for structure, especially in the factor RLS - response to the lack of structure, but not in DFS - desire for structure.

In the extreme groups of women, but not men, divided according to their level of anxiety, significant differences were found in the total score of PNS. Women with low anxiety manifested lower personal need for structure as well.

The positive relation of anxiety with personal need for structure, found by several authors and concerning especially the RLS factor (e.g., Neuberg \& Newsom, 1993; Sarmány-Schuller, 1999b; Sollárová \& Sollár, 2003; Sollár, 2005; Ruiselová, 2000), was also confirmed by the presented research, but only in women, i.e., a significantly higher response to the lack of structure (RLS) and total score of personal need for structure (PNS) were found in women with higher anxiety.

For example, Sarnataro-Smart (2013) found that participants who scored high in the need for simple structure were significantly more likely to experience math anxiety. The author found positive relation between participants' predispositions towards math anxiety and the tendency to adopt a simplified, broad categorical approach to organizing mathematical content. 
In conclusion, the results confirmed the hypothesis concerning the significant relation between personal need for structure and anxiety, and differentiated relation of PNS factors and the studied variables, but only in women, because in men no differences were found between extreme groups in any of the factors, or in total score of personal need for structure.

Due to the fact, that the abovementioned authors made no gender differentiation in their research samples, it is not possible to compare the results obtained only in men with results of other male groups.

Sollár $(2005,2008)$ also considers the study of personal need for structure and anxiety to be important. According to him, a possible focus of further research lies in the study of causality, i.e., whether the degree of PNS and the ability to form cognitive structure leads to anxiety, or if anxiety determines the ability to form simple cognitive structures in specific situations. However, in psychology, the study of causality is very demanding. Currently, our knowledge remains only at the level of disclosing mutual relations.

As stated by Schwarzer (1993), anxiety is closely related to self-efficacy. Although, as already mentioned, there are several researches on the relation between anxiety and personal need for structure, authors do not often focus on the relation between personal need for structure and self-efficacy, and thus we cannot compare our data with data of other authors.

No significant differences in personal need for structure and its subfactors were found in relation to the degree of self-efficacy in men and women. Self-efficacy is negatively related to anxiety in both genders, which is confirmed by Schwarzer (1993), who says that anxiety is related to low self-efficacy, but evidently the relation of personal need for structure to anxiety and to self-efficacy is not identical.

The results indicate that although the significant relation of anxiety and self-efficacy was confirmed, these two mutually related characteristics have a different relation to personal need for structure, i.e., despite anxiety being closely related to self-efficacy, and anxiety in women is related to personal need for structure and response to the lack of structure, this, however, does not mean that self-efficacy will have the same relations to personal need for structure and its subfactors.

In men, as well as in women, self-efficacy is negatively related to pessimism and positively related to optimism, and these relations are stronger in women.

A closer relation of anxiety to personal need for structure is manifested in total optimism. Similarly to the relation of anxiety and personal need for structure and its subfactors, where men manifested no significant differences between extreme groups, the relation of total optimism and personal need for structure including its subfactors showed no significant differences.

On the other hand, in highly optimistic women, similarly to highly anxious women, significant differences were found in the response to the lack of structure and personal need for structure, i.e., more optimistic women have a lower personal need for structure and lower response to the lack of structure, similarly to low anxious women.

The results found no significant relation between pessimism and personal need for structure or its subfactors.

In addition to the studied relation of personal need for structure and anxiety, studied also by other authors (e.g., Sollár, 2005, 2008; 
Sollárová \& Sollár, 2003; and others), research studies of the relation between the need for structure and self-efficacy, or optimism are probably rare, thus we were unable to discuss the presented results in terms of findings of other authors.

\section{Conclusion}

Based on our research results it can be stated that, as opposed to other authors, significant differences between men and women in the score of personal need for structure and its subfactors, desire for structure and response to the lack of structure, were found.

Women manifested higher personal need for structure and its subfactors, which is probably related to the fact that women manifested a relationship between personal need for structure and the studied characteristics more markedly than men did.

High personal need for structure is significantly positively related to high anxiety in women, the higher (or lower) the personal need for structure, the higher (or lower) the anxiety.

Differences in personal need for structure and its subfactors were, however, not confirmed in the extreme groups divided according to pessimism.

No significant differences in the factor desire for structure (DFS) when comparing women, but also men, with different degree of anxiety were found. Desire for structure, which is more of a motivational factor, is probably not closely related to anxiety.

On the other hand, it is not surprising that less anxious women also manifested significantly lower response to the lack of structure (RLS) (more of an affective factor) in comparison to highly anxious women.
These findings confirm the hypothesis that subfactors of personal need for structure are differently related to the studied variables, i.e., it is a confirmation of the different relation of response to the lack of structure and desire for structure to different personality characteristics.

Negative relation of optimism to personal need for structure was confirmed only in women and according to the presented findings; the level of self-efficacy is probably unrelated to personal need for structure and its subfactors.

In conclusion, inconsistency of some of the presented findings with the findings of other authors is obvious and thus they should be verified in further researches and in a much larger sample.

Received November 6, 2014

\section{References}

Bandura, A. (1977). Social learning theory. Englewood Cliffs, NJ: Prentice-Hall.

Bandura, A. (1997). Self-efficacy: The exercise of control. New York: W. H. Freeman.

Budner, S. (1962). Intolerance of ambiguity as a personality variable. Journal of Personality, 30(1), 29-50

Carr, A. (2004). Positive psychology: The science of happiness and human strengths. New York: Routledge.

Cohen, A. R., Stotland, E., \& Wolfe, D. M. (1955). An experimental investigation of need for cognition. Journal of Abnormal Social Psychology, 51(2), 291-294.

DeRoma, V. M., Martin, K. M., \& Kessler, M. L. (2003). The relationship between tolerance for ambiguity and need for course structure. Journal of Instructional Psychology, 30(2), 104109.

Frenkel-Brunswik, E. (1949). Intolerance of ambiguity as an emotional and personality variable. Journal of Personality, 18(1), 108-143.

Furnham, A., \& Ribchester, T. (1995). Tolerance of ambiguity: A review of the concept, its mea- 
surement and applications. Current Psychology, 14(3), 179-199.

Glaesmer, H., Hoyer, J., Klotsche, J., \& Herzberg, P. Y. (2008). Die Deutsche Version des Life Orientation - Tests (LOT-R) zum dispositionellen Optimismus und Pessimismus. Zeitschrift für Gesundheitspsychologie, 16(1), 26-31.

Halama, P., \& Gurňáková, J. (2014). Need for structure and Big Five personality traits as predictors of decision making styles in health professionals. Studia Psychologica, 56(3), 171-180.

Kelly, G. A. (1963). A Theory of Personality: The psychology of personal constructs. W. W. Norton and Company.

Kováč, D. (1985). Teória všeobecnej psychológie. Bratislava: Veda.

Neuberg, S. L., \& Newsom, J. T. (1993). Personal need for structure: Individual differences in the desire for simple structure. Journal of Personality and Social Psychology, 65(1), 113-131.

Rattan, A., Good, C., \& Dweck, C. S. (2012). It's okay - not everyone can be good at math: Instructors with an entity theory confront (and demotivate) students. Journal of Experimental Social Psychology, 48, 731-737.

Ruiselová, Z. (2000). Zvládanie zátaže v kontexte osobnosti adolescentov. In Z. Ruiselová (Ed.), Adjustačné problémy, charakteristiky zvládania a osobnost' adolescentov (pp. 4-15). Bratislava: Ústav Experimentálnej Psychológie SAV.

Sarmány-Schuller, I. (1996). Koncept potreby štruktúry/Slovenské skúsenosti. Vedecká konferencia: Osobnost' v sociálnom kontexte: Kognitívne procesy a stratégie správania. Zlatá Idka, 7.9.11.1996

Sarmány-Schuller, I. (1997). Potreba štruktúry ako bariéra kognitívnej adjustácie adolescentov. In Z. Ruiselová (Ed.), Bariéry kognitívnej a sociálnej adjustácie $u$ adolescentov (pp. 52-68). Bratislava: Ústav Experimentálnej Psychológie SAV.

Sarmány-Schuller, I. (1999a). Procrastination, need for cognition and sensation seeking. Studia Psychologica, 41(1), 73-85.

Sarmány-Schuller, I. (1999b). Neistota-istota (Prípad kauzálnej neistoty. In M. Bratská, E. Naništová, \& I. Sarmány-Schuller (Eds.), Reflexie súčasnej psychológie na Slovensku (pp. 13-19). Bratislava: Stimul.

Sarmány-Schuller, I. (2000a). Need for structure and coping processes. Ansiedad y Estrés, 61(1), 39-45.

Sarmány-Schuller, I. (2000b). Schopnost' vytvárania štruktúry a kategorizácia. In M. Blatný, M
Svoboda, I. Ruisel, \& J. Výrost (Eds.), Sociálni procesy a osobnost, Zborník príspěvků (pp. 185190). Brno: Masarykova univerzita.

Sarmány-Schuller, I. (2001). Potreba štruktúry a schopnost' vytvárania štruktúry ako osobnostné konštrukty. In I. Sarmány-Schuller (Ed.), Psychológia pre bezpečný svet, Zborník príspevkov z XI. Zjazdu SPS (pp. 336-339). Bratislava: Stimul.

Sarnataro-Smart, S. (2013). Personal need for structure: Indiscriminate classification systems as barriers to processing mathematical complexity. Honors Thesis Collection. Paper 110.

Schaller, M., Boyd, C., Yohannes, J., \& O’Brien, M. (1995). The Prejudiced Personality Revisited: Personal Need for Structure and formation of erroneous group stereotypes. Journal of Personality and Social Psychology, 68(3), 544-555.

Scheier, M. F., Carver, C. S., \& Bridges, M. W. (1994). Distinguishing optimism from neuroticism (and trait anxiety, self-mastery, and selfesteem): A reevaluation of the Life Orientation Test). Journal of Personality and Social Psychology, 67, 1063-1078.

Scheier, M. F., Carver, C. S., \& Bridges, M. W. (2001). Optimism, pessimism, and psychological well-being. In E. C. Chang (Ed.), Optimism and pessimism: Implications for theory, research, and practice (pp. 189-216). Washington, APA.

Schwarzer, R. (Ed.) (1993). Measurement of perceived self-efficacy: A documentation of psychometric scales for cross-cultural research. Berlin: Freie University.

Schwarzer, R., \& Jerusalem, M. (1995). Generalized Self-Efficacy Scale. In J. Weinman, S. Wright, \& M. Johnston, Measures in health psychology: A user's portfolio. Causal and control beliefs (pp. 35-37). Windsor, UK: NFER-NELSON.

Sollár, T. (2005). Potreba kognitívnej štruktúry $v$ kontexte osobnostných a interpersonálnych premenných. Bratislava: Ústav Experimentálnej Psychológie SAV, Dizertačná práca.

Sollár, T. (2008). Need for structure from a theoretical and methodological perspective. Studia Psychologica, 50(3), 277-289.

Sollár, T., \& Turzáková, J. (2014). Personal need for structure and control motivation: Linking social cognition and interpersonal motivation. Studia Psychologica, 56(3), 215-220.

Sollár, T., \& Vanečková, J. (2012). Need for closure, ability to achieve closure and monitoringblunting cognitive coping style. Studia Psychologica, 54(2), 137-142. 
Sollárová, E., \& Sollár, T. (2003). Potreba štruktúry a úzkost'. In M. Svoboda, P. Humpolíček, \& J. Humpolíčková (Eds.), Sociální procesy a osobnost 2003. Sbornik přispěvků (pp. 268-273). Brno: Psychologický ústav FF MU, CD ROM.

Sollárová, E., \& Sollár, T. (2010). The psychologically integrated person and parameters of optimal functioning. Studia Psychologica, 52(4), 333-338.

Spielberger, C. D., Jacobs, C., Crane, R., Russel, S., Westberry, L., Barker, L., Johnson, E., Knight, J., \& Marks, E. (1980). Preliminary manual for the State-Trait Personality Inventory (STPI). University of South Florida, Tampa, FL.

Stranovská, E., Sarmány-Schuller, I., Munk, M., \& Munková, D. (2011). Kognitívna štrukturácia v kontexte verbálnej produktivity. In M. Bratská (Ed.), Cesty k múdrosti, Zborník príspevkov, 29. Psychologické dni (pp. 517-524). Bratislava: Stimul.
Thompson, M. M., Naccarato, M. E., \& Parker, K. E. (1989). Assessing cognitive need: The development of the personal need for structure and personal fear of invalidity scales. Annual Meeting of the Canadian Psychological Association, Halifax, Nova Scotia, Canada.

Thompson, M. M., Naccarato, M. E., Parker, K. C. H., \& Moskowitz, G. B. (2001). The personal need for structure and personal fear of invalidity measures: Historical perspectives, current applications, and future directions. In G. B. Moskowitz (Ed.), Cognitive social psychology: The Princeton symposium on the legacy and future of social cognition (pp. 19-40). NJ: Erlbaum.

Wolfradt, U., \& Engelmann, S. (1999). Depersonalization, fantasies, and coping behavior in clinical context. Journal of Clinical Psychology, $55(2), 225-232$.

\section{OSOBNÁ POTREBAŠTRUKTÚRY, ANXIETA, SELF-EFFICACYA OPTIMIZMUS}

\section{A. P rok o p čá k ová}

Súhrn: Ciel'om štúdie je prispiet' k objasneniu vzájomných vzt’ahov potreby štruktúry, anxiety, optimizmu a self-efficacy. Výskumný výber tvorilo 237 vysokoškolských študentov a študentiek (muži $n=48$ a ženy $n=189$ ). Administrovali sme škály: Personal Need for Structure (PNS), Spielberger's Trait personality Inventory (STPI), Generalized Self-Efficacy Scale (GSES) and Life Orientation Test - Revised (LOT-R). Zistili sme signifikantné rozdiely medzi mužmi a ženami $\mathrm{v}$ dosahovanom skóre osobnej potreby štruktúry a jej subfaktoroch - želanie štruktúry a reakcia na chýbanie štruktúry. Ženy manifestovali silnejšiu potrebu štruktúry i jej zložiek. Potreba kognitívnej štruktúry a reakcia na chýbanie štruktúry sa u žien pozitívne spája s úzkostou. Subfaktor želanie štruktúry nevykázal žiadne vzt’ahy so sledovanými charakteristikami. Výsledky u žien ukázali negatívny vzt’ah potreby štruktúry s optimizmom a nezistili sa rozdiely v potrebe štruktúry a jej subfaktorov v závislosti od výšky self-efficacy. 